\title{
Male sex, height, weight, and body mass index can increase external pressure to calf region using knee-crutch-type leg holder system in lithotomy position
}

\author{
This article was published in the following Dove Press journal: \\ Therapeutics and Clinical Risk Management \\ 25 February 2016 \\ Number of times this article has been viewed
}

\author{
Ju Mizuno' \\ Toru Takahashi \\ 'Department of Anesthesiology and \\ Pain Medicine, Juntendo University \\ Faculty of Medicine, Bunkyo-ku, \\ Tokyo, ${ }^{2}$ Faculty of Health and Welfare \\ Science, Okayama Prefectural \\ University, Soja-shi, Okayama, Japan
}

Background: Well-leg compartment syndrome (WLCS) is one of the catastrophic complications related to prolonged surgical procedures performed in the lithotomy position, using a knee-crutchtype leg holder (KCLH) system, to support the popliteal fossae and calf regions. Obesity has been implicated as a risk factor in the lithotomy position-related WLCS during surgery. In the present study, we investigated the relationship between the external pressure (EP) applied to the calf region using a KCLH system in the lithotomy position and selected physical characteristics.

Methods: Twenty-one young, healthy volunteers ( $21.4 \pm 0.5$ years of age, eleven males and ten females) participated in this study. The KCLH system used was Knee Crutch ${ }^{\circledR}$. We assessed four types of EPs applied to the calf region: box pressure, peak box pressure, contact pressure, and peak contact pressure, using pressure-distribution measurement system (BIG-MAT ${ }^{\circledR}$ ). Relationships between these four EPs to the calf regions of both lower legs and a series of physical characteristics (sex, height, weight, and body mass index [BMI]) were analyzed.

Results: All four EPs applied to the bilateral calf regions were higher in males than in females. For all subjects, significant positive correlations were observed between all four EPs and height, weight, and BMI.

Conclusion: EP applied to the calf region is higher in males than in females when the subject is supported by a KCLH system in the lithotomy position. In addition, EP increases with the increase in height, weight, and BMI. Therefore, male sex, height, weight, and BMI may contribute to the risk of inducing WLCS.

Keywords: well-leg compartment syndrome, pressure-distribution measurement system, peak contact pressure, physical characteristics, obesity

\section{Introduction}

Well-leg compartment syndrome (WLCS) associated with prolonged surgical procedures performed in the lithotomy position, such as those involving the pelvic viscera and perineum in urological, colorectal, and gynecological surgeries, is a rare event. However, WLCS may result in catastrophic complications, such as calf swelling, weakness of toe flexion, foot drop, pain during passive toe extension, paresthesia, significant muscle loss, rhabdomyolysis, muscle necrosis, metabolic acidosis, myoglobinuric renal failure, lower extremity amputation, permanent disability, and even death. ${ }^{1-6}$ The overall incidence of WLCS following major pelvic surgery performed in the lithotomy position has been estimated to be one in 3,500 cases. ${ }^{7}$ WLCS is related to compartmental syndromes where increased pressure within the nonexpansible
Correspondence: Ju Mizuno

Department of Anesthesiology and Pain Medicine, Juntendo University Faculty of Medicine, 3-I-3 Hongo, Bunkyo-ku, Tokyo II3-843I, Japan

Tel $+813381331 \mathrm{II}$

Fax +8I 356893820

Email mizuno_ju8@yahoo.co.jp 
fascial compartments in lower leg compromises the circulation, resulting in ischemia, which further causes edema and reperfusion injury, resulting in an abnormally increased intracompartmental pressure (ICP). Intramuscular pressure increases due to external compression from the calf support, while perfusion pressure (PP) decreases due to elevation in the lithotomy position. Therefore, WLCS has been observed after prolonged compression of the calf muscles, which lie in contact with a knee-crutch-type leg holder (KCLH) system supporting the popliteal fossae and calf regions during prolonged surgical procedures performed in the lithotomy position. Decreased PP due to calf compression and leg elevation in the lithotomy position may be one of the most important underlying factors for the onset of WLCS.

The definitive diagnosis of WLCS is made by the direct measurement of ICP. ${ }^{8,9}$ In routine, ICP can be invasively measured by using a simple needle manometer, continuous infusion, wick catheter, slit catheter, or solid-state transducer method. A noninvasive diagnosis of chronic compartment syndrome can be made by measuring variations in the level of muscle hemoglobin and myoglobin oxygen saturation by near-infrared spectroscopy ${ }^{10}$ and continuous measurement of the laser Doppler flow in muscles. ${ }^{11}$ Alternatively, the pressure-distribution measurement system, BIG-MAT ${ }^{\circledR}$ (Nitta, Osaka, Japan), is a noninvasive method to measure external pressure (EP) for industrial applications. ${ }^{12}$ In our previous studies, we have used the BIG-MAT ${ }^{\circledR}$ system in the medical field to measure EP in certain fibular regions to investigate the cause of common peroneal nerve paralysis using the KCLH system in the lithotomy position. ${ }^{13,14}$

It is known that obesity can induce WLCS. ${ }^{15}$ However, it is not clear why only selective patients develop WLCS. We hypothesized that subject-related physical characteristics, such as sex, height, weight, and body mass index (BMI), induce lithotomy position-related WLCS. In the present study, we investigated the relationships between the EP applied to the calf regions using a KCLH system in the lithotomy position and a series of subject-specific physical characteristics of volunteer subjects. Therefore, the aim of this study was to characterize sex differences in soft tissue quality in healthy adults and identify the potential risk factors for WLCS in the lithotomy position, in order to suggest prevention strategies.

\section{Methods}

Our study was approved (approval number 307) by the ethics committee of Okayama Prefectural University; 21 young, healthy university students (21-22 years of age, eleven males and ten females) were recruited as volunteers. Subjects with diabetes mellitus or motor and sensory disturbances in the lower extremities were excluded. Before starting the study, written informed consent was obtained and height, weight, and BMI were measured for each subject.

First, the KCLH system Knee Crutch $^{\circledR}(L 27 \mathrm{~cm} \times$ $W 16 \mathrm{~cm} \times D 6 \mathrm{~cm}$; Takara Belmont, Osaka, Japan), which supports the popliteal fossae and calf regions and extends a short-distance cephalad on the dorsal thigh and a longdistance one caudally on the posterior aspect of the lower leg in the lithotomy position, was connected to a class IB ${ }^{\circledR}$ electric operating table (Takara Belmont).

Next, a pressure-distribution measurement sheet BIG$\operatorname{MAT2000P3BS}^{\circledR}(L 440 \mathrm{~mm} \times W 480 \mathrm{~mm} \times D 0.4 \mathrm{~mm}$; Nitta) was spread over the Knee Crutch $^{\circledR}$. The BIG-MAT ${ }^{\circledR}$ system was calibrated by careful placement of a $25-\mathrm{kg}$ concrete block. Digital values were converted to pressure information using a personal computer with built-in BIGMAT $^{\circledR}$ software (Nitta), which displayed two-dimensional, visually understandable separate squares for 2,112 sensor cells. Outputs from all sensor cells were displayed as a number within the range of $0-255$. Changes in pressure values were consecutively recorded, and chronological changes were saved as movie files on the personal computer; 100 pressure-distribution views were recorded per subject followed by the measurement of the EP distribution for the BIG-MAT2000P3BS ${ }^{\circledR}$ sheet.

During the measurement, the subjects were asked to lie down in the lithotomy position on a mattress covering the class $\mathrm{IB}^{\circledR}$ and were kept awake in the laboratory. Both knees and lower legs were placed on the BIG-MAT2000P3BS ${ }^{\circledR}$ sheet spread over a Knee Crutch $^{\circledR}$ (Figure 1). By using the angle gauge, both hip joints were flexed at $90^{\circ}$ from the trunk, externally rotated at $40^{\circ}$ from the midline, and abducted at $20^{\circ}$; and both knee joints were flexed at $90^{\circ}$ until both lower legs were parallel to the class IB ${ }^{\circledR} .{ }^{16} \mathrm{We}$ measured and recorded the EP distribution in the calf regions of both lower legs using the BIG-MAT ${ }^{\circledR}$ system in the neutral state.

We selected the box corresponding to the calf regions on the display and analyzed the load value (LV), which represented the total loading value and the four EPs in the box: box pressure (BP), peak box pressure (PBP), contact pressure (CP), and peak contact pressure (PCP). BP represented the total pressure in all cells loaded in the box, which was equal to the total loading value divided by the total area of the box. PBP represented the total pressure in the peak area that corresponded to $2 \times 2$ loaded cells, showing the highest value in the box, which was equal to the total loading value in the peak area divided by the peak area. $\mathrm{CP}$ represented the 


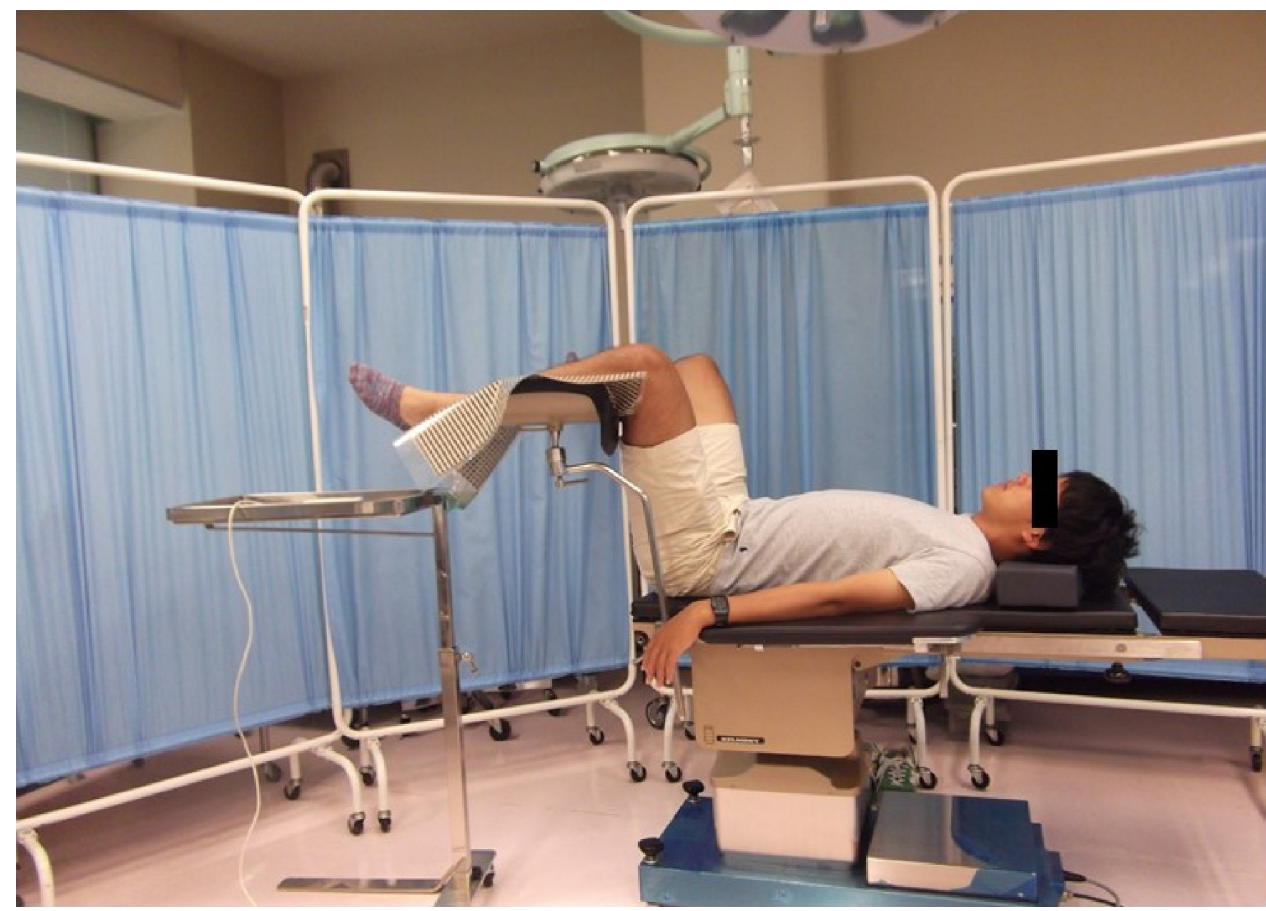

Figure I Lithotomy position.

Note: The subject's left knee and lower leg were placed on a BIG-MAT2000P3BS ${ }^{\circledR}$ sheet spread over a Knee Crutch $^{\circledR}$.

pressure in the loaded cells in the box, which was equal to the total loading value divided by the loaded cell area. PCP represented the pressure in the loaded cells in the peak area, which was equal to the total loading value divided by the loaded cell area in the peak area.

Analyses were performed using Excel $2013^{\circledR}$ (Microsoft, Redmond, WA, USA) and DeltaGraph 5.4.5 $\mathrm{vJ}^{\circledR}$ (Deltapoint, Monterey, CA, USA) software. BMI was calculated as weight $(\mathrm{kg}) /(\text { height }[\mathrm{m}])^{2}$. Values were expressed as mean \pm standard deviation. Student's $t$-test (paired or unpaired) was used for statistical comparison. Simple linear regression analyses were performed to determine correlations between LV or four EPs and subject-specific physical characteristics (sex, height, weight, and BMI). A $P$-value of $<0.05$ was considered to be significant.

\section{Results}

\section{Physical characteristics}

The age, sex, height, weight, and BMI of the 21 volunteer subjects are shown in Table 1.

\section{$\mathrm{LV}$ and EPs}

Figure 2 shows representative pressure-distribution values recorded for contact of the left popliteal fossa and calf region when using a Knee Crutch $^{\circledR}$. LV and the four EPs to the bilateral calf regions were greater in males than in females
(Table 2) and significantly increased with the increase in height, weight, and BMI for all the subjects $(P<0.05$; Figure 3).

\section{Discussion}

The primary novel findings of the current study were that LV and the four EPs to the calf regions of both lower legs were greater in males than in females and increased with the increase in height, weight, and BMI when patients were held in the lithotomy position and supported by a KCLH system. Male sex, height, weight, and BMI may present potential risk factors for WLCS in the lithotomy position.

\section{External pressure}

The compressive KCLH system may obstruct or retard venous and lymphatic return, increase the risk of hypoperfusion

Table I Physical characteristics

\begin{tabular}{llll}
\hline & $\begin{array}{l}\text { All subjects } \\
(\mathbf{n}=\mathbf{2})\end{array}$ & $\begin{array}{l}\text { Males } \\
(\mathbf{n}=\mathbf{I})\end{array}$ & $\begin{array}{l}\text { Females } \\
(\mathbf{n}=\mathbf{1 0})\end{array}$ \\
\hline Age (years) & $21.4 \pm 0.5$ & $21.5 \pm 0.5$ & $21.4 \pm 0.5$ \\
Height $(\mathrm{cm})$ & $167.5 \pm 10.0$ & $175.0 \pm 6.3^{* *}$ & $159.3 \pm 5.7$ \\
Weight $(\mathrm{kg})$ & $60.7 \pm 12.8$ & $70.0 \pm 8.6 * *$ & $50.4 \pm 7.6$ \\
BMI $\left(\mathrm{kg} / \mathrm{m}^{2}\right)$ & $21.4 \pm 3.0$ & $22.9 \pm 2.8^{*}$ & $19.8 \pm 2.4$ \\
\hline
\end{tabular}

Notes: $* P<0.05, * * P<0.001$ versus females. Data expressed as mean \pm standard deviation.

Abbreviation: BMI, body mass index. 


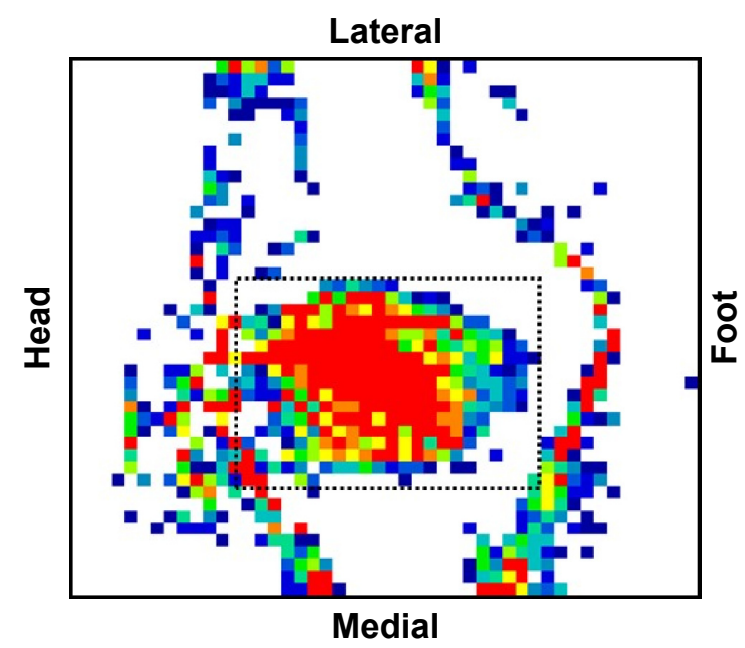

Figure 2 Representative pressure-distribution view at the surface of the left popliteal fossa and calf region in contact with the left Knee Crutch ${ }^{\circledast}$ measured using the BIG-MAT ${ }^{\circledR}$ system in the lithotomy position.

Notes: High-pressure areas are shown with red squares, while low-pressure areas are shown with blue squares. The dotted-line square box shows the left calf region.

to the lower extremities, and increase ICP. When EP compresses the skin and feeding vessels at the calf regions, blood flow in the peripheral vessels stops and the adjacent muscles and nerves are exposed to ischemia. Consequent occlusion of the venous circulation leads to functional loss of the muscular tissues in this region, and the ensuing muscle necrosis leads to rhabdomyolysis. A previous study reported that capillary blood pressure in the canine muscle was $25 \mathrm{mmHg} .{ }^{17}$ Another study reported that capillary blood pressure in human

Table 2 LV and four EPs to the calf regions using the Knee Crutch $^{\circledR}$ in the lithotomy position

\begin{tabular}{clll}
\hline & $\begin{array}{l}\text { All subjects } \\
(\mathbf{n}=\mathbf{2} \mathbf{I})\end{array}$ & $\begin{array}{l}\text { Males } \\
(\mathbf{n}=\mathbf{I I})\end{array}$ & $\begin{array}{l}\text { Females } \\
(\mathbf{n}=\mathbf{I} \mathbf{0})\end{array}$ \\
\hline Bilateral LV $(\mathrm{kg})$ & $10.2 \pm 3.0$ & $12.1 \pm 2.5^{* *}$ & $8.1 \pm 1.9$ \\
Right LV $(\mathrm{kg})$ & $10.4 \pm 3.1$ & $12.7 \pm 2.3^{* *}$ & $8.0 \pm 1.8$ \\
Left LV $(\mathrm{kg})$ & $9.9 \pm 2.9$ & $11.5 \pm 2.6^{*}$ & $8.1 \pm 2.0$ \\
Bilateral BP $(\mathrm{mmHg})$ & $15.7 \pm 2.9$ & $17.0 \pm 2.4^{* *}$ & $14.2 \pm 2.6$ \\
Right BP $(\mathrm{mmHg})$ & $15.6 \pm 3.2$ & $17.5 \pm 2.5^{* *}$ & $13.4 \pm 2.4^{\dagger}$ \\
Left BP $(\mathrm{mmHg})$ & $15.8 \pm 2.6$ & $16.5 \pm 2.3$ & $14.9 \pm 2.8$ \\
Bilateral PBP $(\mathrm{mmHg})$ & $55.8 \pm 31.1$ & $69.5 \pm 36.6^{*}$ & $40.7 \pm 12.4$ \\
Right PBP $(\mathrm{mmHg})$ & $57.9 \pm 34.4$ & $73.8 \pm 41.1^{*}$ & $40.4 \pm 10.4$ \\
Left PBP $(\mathrm{mmHg})$ & $53.7 \pm 28.2$ & $65.3 \pm 33.0^{*}$ & $41.0 \pm 14.7$ \\
Bilateral CP $(\mathrm{mmHg})$ & $22.7 \pm 3.4$ & $24.3 \pm 3.0^{* *}$ & $21.0 \pm 2.9$ \\
Right CP $(\mathrm{mmHg})$ & $23.0 \pm 3.5$ & $24.8 \pm 3.4^{*}$ & $18.6 \pm 2.6$ \\
Left CP $(\mathrm{mmHg})$ & $22.4 \pm 3.3$ & $23.7 \pm 2.7^{*}$ & $20.9 \pm 3.4$ \\
Bilateral PCP $(\mathrm{mmHg})$ & $58.4 \pm 36.4$ & $73.8 \pm 43.8^{*}$ & $41.4 \pm 12.7$ \\
Right PCP $(\mathrm{mmHg})$ & $63.0 \pm 43.4$ & $82.4 \pm 52.7^{*}$ & $41.7 \pm 11.1$ \\
Left PCP $(\mathrm{mmHg})$ & $53.7 \pm 28.2$ & $65.3 \pm 33.0^{*}$ & $41.0 \pm 14.7$ \\
\hline Notes: &
\end{tabular}

Notes: $* P<0.05, * * P<0.001$ versus females; ${ }^{+P}<0.05$ versus left. Data expressed as mean \pm standard deviation.

Abbreviations: LV, load value; EP, external pressure; BP, box pressure; PBP, peak box pressure; $\mathrm{CP}$, contact pressure; $\mathrm{PCP}$, peak contact pressure. skin was $32 \mathrm{mmHg}$ with microinjection. ${ }^{18} \mathrm{EP}>32 \mathrm{mmHg}$ is known to induce the occlusion of capillary vessels and ischemic nerve injury. Therefore, it is recommended that EP loading to the skin surface should be kept $<32 \mathrm{mmHg}$ and as low as possible. ${ }^{19}$ Another study reported that the pressureflow curve in the skeletal muscle tissue was curvilinear, with convexity toward the flow axis, and that compression with a pressure of $60 \mathrm{mmHg}$ reduced muscle blood flow to $41 \%$ of the reference value, while local vascular resistance increased by $32 \%$ above the reference value. ${ }^{20}$ Any complication associated with reduced blood supply may increase the risk of ischemic injury. In the present study, the mean PCP to the bilateral calf regions was $58.4 \mathrm{mmHg}$ for all subjects, which was significantly higher than the $32 \mathrm{mmHg}$ threshold $(P<0.001)$. These results indicate that EP to the calf region using the KCLH system in the lithotomy position can lead to WLCS.

\section{Perfusion pressure}

It has been shown that placing lower extremities in the lithotomy position in an anesthetized patient can cause a reduction in the blood pressure in the lower extremities and a rise in ICP. ${ }^{7,21}$ This reduction is $\sim 10 \mathrm{mmHg}$ compared to the systolic pressure in the supine position. For every centimeter that an extremity is raised above the right atrium, PP is reduced by $0.78 \mathrm{mmHg} .{ }^{22,23}$ Hypoperfusion pressure can reduce blood flow, which prevents nutrient and oxygen supply to the muscle cells. During elevation of the lower leg for 25 minutes, mean arterial pressure reduced from 100 to $77 \mathrm{mmHg}$, while PP dropped from 103 to $21 \mathrm{mmHg}$, corresponding to a reduction in the oxygen saturation of the medial gastrocnemius muscle from $68 \%$ to $58 \%$. These results demonstrated significant desaturation of the calf muscles during surgery performed in the lithotomy position. ${ }^{24}$ WLCS is attributable to prolonged impairment of lower extremity perfusion secondary to an increase in ICP within a closed fascial space. Reduction in PP causes tissue ischemia, which may be followed by reperfusion, with subsequent capillary leakage and tissue edema. Consequently, abnormal hydrostatic and oncotic pressure inside the intravascular and tissue spaces cause local ischemia, acidosis, and cell death, resulting in a vicious circle of tissue edema and impairment of perfusion.

\section{Intracompartmental pressure}

Persistently elevated EP leads to a repeated cycle of increasing intramuscular pressure and ischemia within the compartment. Clinical studies have reported a significant 

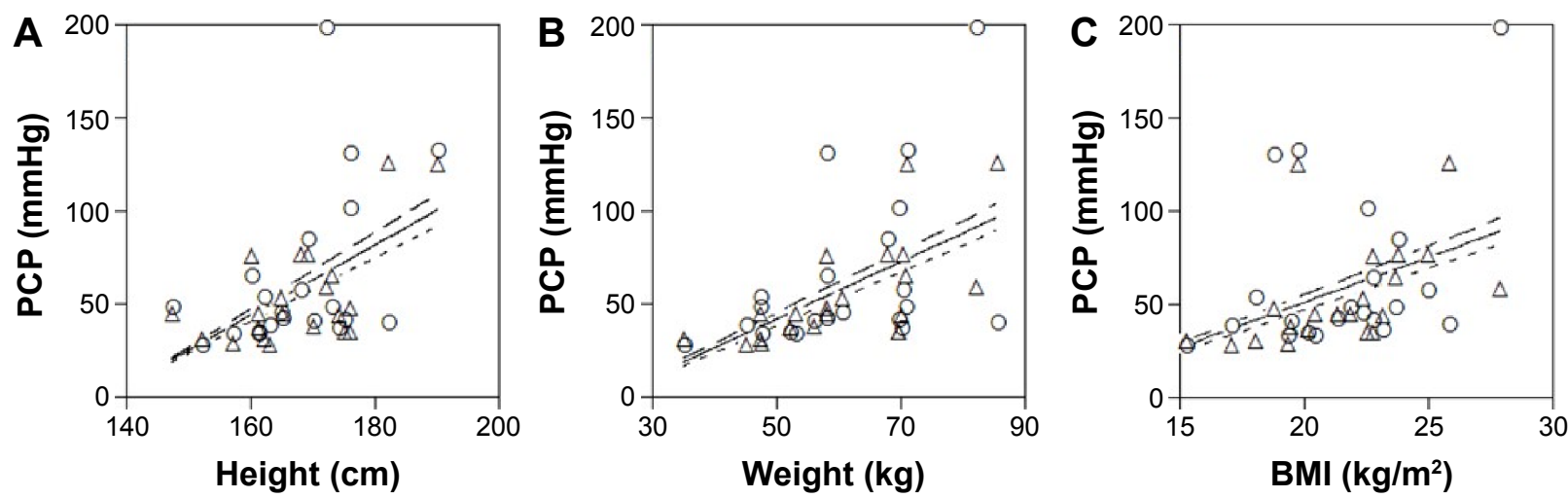

Figure 3 Relationship between peak contact pressure (PCP) to the calf region and the physical characteristics of all subjects using the Knee Crutch ${ }^{\circledR}$ in the lithotomy position.

Notes: Circles and triangles show PCP to the right and left calf regions, respectively. Solid, dashed, and dotted simple regression linear lines show relationships between PCP to the bilateral, right, and left calf regions and three physical characteristics of the subjects (height, weight, or body mass index [BMI]). (A) Height: solid line, PCP $(\mathrm{mmHg})=\mathrm{I} .88 \times$ height $(\mathrm{cm})-256(r=0.5 \mathrm{I}, P=0.00 \mathrm{I})$; dashed line, $\mathrm{PCP}(\mathrm{mmHg})=2.05 \times$ height $(\mathrm{cm})-28 \mathrm{I}(r=0.47, P=0.03 \mathrm{I})$; and dotted line, $\mathrm{PCP}(\mathrm{mmHg})=\mathrm{I} .7 \mathrm{I} \times$ height $(\mathrm{cm})-232$ $(r=0.60, P=0.004)$. (B) Weight: solid line, $P C P(\mathrm{mmHg})=1.54 \times$ weight $(\mathrm{kg})-34.9(r=0.53, P=0.000)$; dashed line, $P C P(\mathrm{mmHg})=1.64 \times$ weight $(\mathrm{kg})-36.5(r=0.48, P=0.026)$; and dotted line, PCP $(\mathrm{mmHg})=1.44 \times$ weight $(\mathrm{kg})-33.4(r=0.65, P=0.00 \mathrm{I})$. (C) BMl: solid line, PCP $(\mathrm{mmHg})=4.85 \times \mathrm{BMI}\left(\mathrm{kg} / \mathrm{m}^{2}\right)-45.5(r=0.40, P=0.009) ;$ dashed line, $\mathrm{PCP}$ $(\mathrm{mmHg})=5.2 \mathrm{I} \times \mathrm{BMI}\left(\mathrm{kg} / \mathrm{m}^{2}\right)-48.6(r=0.36, P=0.107) ;$ and dotted line, $\mathrm{PCP}(\mathrm{mmHg})=4.48 \times \mathrm{BMI}\left(\mathrm{kg} / \mathrm{m}^{2}\right)-42.3(r=0.48, P=0.028)$.

increase in the venous pressure of the great saphenous vein in the lithotomy position compared with the supine position. ${ }^{25}$ The lithotomy position with support behind the calf or knee increases ICP within the tibialis anterior muscle compartment to 16.5 versus $10.7 \mathrm{mmHg}$ in the supine position. ${ }^{26}$ Initially, venous drainage is impeded, but arterial supply is compromised eventually. Ultimately, WLCS is initiated when ICP approaches or exceeds systemic diastolic blood pressure (DBP).

There is no universal agreement on the precise ICP at which we should consider intervention. The normal range of ICP during surgery is between 0 and $10 \mathrm{mmHg}$. One study reported a significant risk of damage in the canine muscle when ICP exceeded $30 \mathrm{mmHg} .{ }^{17}$ Therefore, skeletal muscle necrosis occurs in conjunction with an absolute ICP of over $30 \mathrm{mmHg}$. Many surgeons now use the measured ICP of $30 \mathrm{mmHg}$ as an indication for fasciotomy. ${ }^{27-29}$ Another report recommended that surgical decompression should be performed if the differential pressure level between DBP and ICP drops below $30 \mathrm{mmHg}{ }^{30}$

The combination of increased ICP due to external compression from the calf support and reduced PP due to the elevated position causes a significant reduction in the difference between DBP and ICP when the knee and lower leg are placed in a KCLH system in the lithotomy position. Therefore, positioning the knee and lower leg below the level of the atrium is highly recommended.

\section{Obesity}

Obesity has been reported as a risk factor for WLCS. ${ }^{31}$ Another risk factor associated with the development of
WLCS is high BMI. ${ }^{32}$ Rhabdomyolysis in overweight patients with WLCS is frequently reported after prolonged surgical procedures performed in the lithotomy position. ${ }^{6}$ The metabolism of obese patients is probably an additional risk factor to the gravitational effect of obesity itself. In this study, weight and BMI were positively correlated with the four EPs. Our previous study showed that PCP to the fibular head region using the Knee Crutch $^{\circledR}$ increased with both weight and BMI. ${ }^{14}$ These findings indicate that EP to the calf in the lithotomy position increased along with an increase in weight and BMI.

We speculate that WLCS following surgery performed in the lithotomy position is related to three main components: body mass, gravitation, and the KCLH system. The size of the KCLH system should therefore be changed in accordance with the subject's physical characteristics, particularly for obesity. Further research is required to investigate the precise risk associated with metabolic disorder and obesity.

In the present study, BMI for all subjects was $21.4 \pm 3.0 \mathrm{~kg} / \mathrm{m}^{2}$ with only limited variation. Future studies should be conducted to investigate the relationship between $\mathrm{EP}$ and BMI, including both underweight and obese subjects.

\section{Sex}

In this study, the mean PCP to the bilateral calf regions using the Knee Crutch ${ }^{\circledR}$ for young males and females was 73.8 and $41.4 \mathrm{mmHg}$, respectively, and the four EPs to the bilateral calf regions were higher in males than in females. In our previous study, PCP to the fibular head region using the Knee Crutch $^{\circledR}$ was higher in males than in females. ${ }^{14}$ 
Body compositions, such as tissue mass and area, frequently differ between males and females. Generally, males are taller and heavier than females. The body muscle percentage, leg bone-free lean mass, calf muscle cross-sectional area, and calf muscle density are also greater in males than in females, whereas the opposite is true for body fat percentage, leg fat mass, calf fat cross-sectional area, and calf fat density. ${ }^{33}$

These findings indicate that EP to the calf region in the lithotomy position supported by a KCLH system may be higher in males than in females. Consequently, surgeons should consider the potential effects of the KCLH system in relation to sex while planning surgical procedures in the lithotomy position.

\section{Study limitations}

The etiology of WLCS is multifactorial; ${ }^{31}$ emphasis must be placed on the identification of high-risk patients, prevention or rapid correction of any etiological factors, early diagnosis of the problem, and an aggressive treatment approach. ${ }^{1,34,35}$

First, we selected four EPs as representatives using the BIG-MAT ${ }^{\circledR}$ system. We were unable to gather clear evidence on the correlation between the four indices measured (BP, PBP, CP, and PCP) and the actual PP and ICP, although we have previously reported PCP using the BIG-MAT ${ }^{\circledR}$ system. ${ }^{13,14}$ Therefore, we need to obtain additional data on the correlation between measurements with the BIG-MAT ${ }^{\circledR}$ system and invasive pressure measurements, such as PP and ICP.

Second, most cases of WLCS occur following operation under general anesthesia. A conscious, prolonged position that causes muscle compression gradually results in discomfort. During general anesthesia, patients do not experience discomfort and are unable to control the lithotomy position. Therefore, we need to measure LV and the four EPs in subjects with the use of sedation, analgesia, and a muscle relaxant.

Third, the subjects of this study were young, healthy adults. In the future, such studies should involve geriatric patients; smokers; ${ }^{31}$ patients with chronic hemodialysis; ${ }^{36}$ patients with preexisting systemic diseases, such as diabetes mellitus, ${ }^{31,37,38}$ hypertension, hyperlipidemia, peripheral vascular disease $;^{31,39}$ and patients with anatomical variations resulting in reduced blood flow to the lower extremities.

Fourth, prolonged operative duration, massive blood loss during surgery, and significant intraoperative hypotension are the risk factors for the development of WLCS. ${ }^{32}$ ICP shows minor elevations after initial lithotomy positioning and gradually increases, with levels rising to $30 \mathrm{mmHg}$ over an average period of 5 hours. ${ }^{40}$ The canine skeletal muscle necrosis associated with impending compartment syndrome occurs at a threshold ICP of $30 \mathrm{mmHg}$ after 8 hours. ${ }^{41}$ However, time variables are often unknown in suspected compartment syndromes. Combined with a prolonged surgical time, the lithotomy position may cause WLCS using the KCLH system. The duration of surgery should be as short as possible in order to reduce the extra risk in obese patients. Therefore, we need to measure LV and the four EPs in subjects continuously for a long period.

Fifth, increase in PCP during surgery in the lithotomy position with support near the calf may be one of the factors that contribute to the development of WLCS. In contrast, the lithotomy position with support near the ankle reduces ICP within the tibialis anterior muscle compartment to $8.7 \mathrm{mmHg}$ compared to $13.3 \mathrm{mmHg}$ in the supine position. ${ }^{26}$ Changing from a calf-supported to a heel-supported position significantly reduced intramuscular pressure within the compartments. ${ }^{42}$ Instead of using a KCLH system, leaving the calf free increases the difference between ICP and DBP and may, therefore, reduce the risk of WLCS.

Finally, because the BIG-MAT ${ }^{\circledR}$ system is not currently approved for clinical use as a medical instrument, it can only be used in clinical studies with the approval of relevant ethics committees.

\section{Conclusion}

EP to the calf region is higher in males than in females in the lithotomy position supported by a KCLH system and increases with the increase in height, weight, and BMI. Therefore, male sex, height, weight, and BMI represent factors that can increase EP and may contribute to the risk of inducing WLCS. An EP dispersion leg holder system should be expended for surgical procedures in the lithotomy position according to the physical characteristics of the subjects analyzed.

\section{Acknowledgment}

The authors thank the students of Okayama Prefectural University who participated as volunteers in this study.

\section{Disclosure}

The authors report no conflicts of interest in this work.

\section{References}

1. Leff RG, Shapiro SR. Lower extremity complications of the lithotomy position: prevention and management. J Urol. 1979;122:138-139.

2. Heppenstall B, Tan V. Well-leg compartment syndrome. Lancet. 1999; 354:970. 
3. Khalil IM. Bilateral compartmental syndrome after prolonged surgery in the lithotomy position. J Vasc Surg. 1987;5:879-881.

4. Verdolin MH, Toth AS, Schroeder R. Bilateral lower extremity compartment syndromes following prolonged surgery in the low lithotomy position with serial compression stockings. Anesthesiology. 2000;92: 1189-1191.

5. Prakash C, Bonajmash AA, Ahmed A. A case of acute compartment syndrome of the leg following prolonged lithotomy position during urological surgery. Int J Case Rep Imag. 2011;2:19-22.

6. Işer IC, Senkul T, Reddy PK. Major urologic surgery and rhabdomyolysis in two obese patients. Int J Urol. 2003;10:558-560.

7. Halliwill JR, Hewitt SA, Joyner MJ, Warner MA. Effect of various lithotomy positions on lower-extremity blood pressure. Anesthesiology. 1998;89:1373-1376

8. Matsen FA 3rd, Mayo KA, Sheridan GW, Krugmire RB Jr. Monitoring of intramuscular pressure. Surgery. 1976;79:702-709.

9. Matsen FA 3rd, Winquist RA, Krugmire RB Jr. Diagnosis and management of compartmental syndromes. J Bone Joint Surg Am. 1980;62: 286-291.

10. Breit GA, Gross JH, Watenpaugh DE, Chance B, Hargens AR. Nearinfrared spectroscopy for monitoring of tissue oxygenation of exercising skeletal muscle in a chronic compartment syndrome model. J Bone Joint Surg Am. 1997;79:838-843.

11. Abraham P, Leftheriotis G, Saumet JL. Laser Doppler flowmetry in the diagnosis of chronic compartment syndrome. J Bone Joint Surg Br. 1998;80:365-369.

12. Sato S, Mizuma M, Kawate N, Kasai F, Watanabe H. Evaluation of sit-to-stand motion using a pressure distribution measurement system effect of differences in seat hardness on sit-to-stand motion. Disabil Rehabil Assist Technol. 2011;6:290-298.

13. Mizuno J, Namba C, Takahashi T. Measurement of external pressure of peroneal nerve tract coming in contact with lithotomy leg holders using pressure distribution measurement system BIG-MAT ${ }^{\circledR}$. Masui. 2014;63:1167-1171.

14. Mizuno J, Takahashi T. Factors that increase external pressure to the fibular head region, but not medial region, during use of a knee crutch/ leg holder system in the lithotomy position. Ther Clin Risk Manag. 2015;11:255-261.

15. Ikeya E, Taguchi J, Ohta K, et al. Compartment syndrome of bilateral lower extremities following laparoscopic surgery of rectal cancer in lithotomy position: report of a case. Surg Today. 2006;36:1122-1125.

16. Lee JW, Cassorla L. Lithotomy, specific positions, patient positioning and associated risks. In: Miller RD, 1Pardo MC Jr, editors. Basics of Anesthesia. 6th ed. Philadelphia: Elsevier Saunders; 2011:304-305.

17. Hargens AR, Akeson WH, Mubarak SJ, et al. Fluid balance within the canine anterolateral compartment and its relationship to compartment syndromes. J Bone Joint Surg Am. 1978;60:499-505.

18. Landis EM. Micro-injection studies of capillary blood pressure in human skin. Heart. 1930;15:209-228

19. Krouskop TA, Garber SL. Interface pressure measurements. J Enterostomal Ther. 1990;17:182.

20. Nielsen HV. Effects of externally applied compression on blood flow in subcutaneous and muscle tissue in the human supine leg. Clin Physiol. 1982;2:447-457.

21. Turnbull D, Farid A, Hutchinson S, Shorthouse A, Mills GH. Calf compartment pressures in the Lloyd-Davies position: a cause for concern? Anaesthesia. 2002;57:905-908.

22. Matsen FA 3rd. A practical approach to compartmental syndromes. Part I. Definition, theory, and pathogenesis. Instr Course Lect. 1983;32: 88-92.
23. Mumtaz FH, Chew H, Gelister JS. Lower limb compartment syndrome associated with the lithotomy position: concepts and perspectives for the urologist. BJU Int. 2002;90:792-799.

24. Svendsen LB, Flink P, Wøjdemann M, Riber C, Mogensen T, Secher NH. Muscle oxygen saturation during surgery in the lithotomy position. Clin Physiol. 1997;17:433-438.

25. Liu X, Wang X, Meng X, Wang H, An Z. Effects of patient position on lower extremity venous pressure during different types of hysterectomy. J Obstet Gynaecol Res. 2014;10:12489.

26. Pfeffer SD, Halliwill JR, Warner MA. Effects of lithotomy position and external compression on lower leg muscle compartment pressure. Anesthesiology. 2001;95:632-636.

27. Mubarak SJ, Pedowitz RA, Hargens AR. Compartment syndromes. Curr Orthop. 1989;3:36-40.

28. Köstler W, Strohm PC, Südkamp NP. Acute compartment syndrome of the limb. Injury. 2005;36:992-998.

29. Cohen MS, Garfin SR, Hargens AR, Mubarak SJ. Acute compartment syndrome. Effect of dermotomy on fascial decompression in the leg. J Bone Joint Surg Br. 1991;73:287-290.

30. McQueen MM, Court-Brown CM. Compartment monitoring in tibial fractures. The pressure threshold for decompression. JBone Joint Surg Br. 1996;78:99-104

31. Raza A, Byrne D, Townell N. Lower limb (well leg) compartment syndrome after urological pelvic surgery. J Urol. 2004;171:5-11.

32. Simms MS, Terry TR. Well leg compartment syndrome after pelvic and perineal surgery in the lithotomy position. Postgrad Med J. 2005; 81:534-536

33. Sherk VD, Thiebaud RS, Chen Z, Karabulut M, Kim SJ, Bemben DA. Associations between pQCT-based fat and muscle area and density and DXA-based total and leg soft tissue mass in healthy women and men. J Musculoskelet Neuronal Interact. 2014;14:411-417.

34. Mulhall JP, Drezner AD. Postoperative compartment syndrome and the lithotomy position: a report of three cases and analysis of potential risk factors. Conn Med. 1993;57:129-133.

35. Scott JR, Daneker G, Lumsden AB. Prevention of compartment syndrome associated with dorsal lithotomy position. Am Surg. 1997;63: 801-806.

36. Kaya T, Sipahi S, Karacaer C, et al. Evaluation of nutritional status with different methods in geriatric hemodialysis patients: impact of gender. Int Urol Nephrol. 2014;46:2385-2391.

37. Stamboulis E, Vassilopoulos D, Kalfakis N. Symptomatic focal mononeuropathies in diabetic patients: increased or not? J Neurol. 2005;252: 448-452.

38. Massey EW, Pleet AB. Compression injury of the sciatic nerve during a prolonged surgical procedure in a diabetic patient. J Am Geriatr Soc. 1980;28:188-189.

39. Raval Z, Liu K, Tian L, et al. Higher body mass index is associated with more adverse changes in calf muscle characteristics in peripheral arterial disease. J Vasc Surg. 2012;55:1015-1024.

40. Chase J, Harford F, Pinzur MS, Zussman M. Intraoperative lower extremity compartment pressures in lithotomy-positioned patients. Dis Colon Rectum. 2000;43:678-680.

41. Hargens AR, Schmidt DA, Evans KL, et al. Quantitation of skeletalmuscle necrosis in a model compartment syndrome. J Bone Joint Surg Am. 1981;63:631-636.

42. Meyer RS, White KK, Smith JM, Groppo ER, Mubarak SJ, Hargens AR. Intramuscular and blood pressures in legs positioned in the hemilithotomy position: clarification of risk factors for well-leg acute compartment syndrome. J Bone Joint Surg Am. 2002;84-A:1829-1835. 


\section{Publish your work in this journal}

Therapeutics and Clinical Risk Management is an international, peerreviewed journal of clinical therapeutics and risk management, focusing on concise rapid reporting of clinical studies in all therapeutic areas, outcomes, safety, and programs for the effective, safe, and sustained use of medicines. This journal is indexed on PubMed Central, CAS,

EMBase, Scopus and the Elsevier Bibliographic databases. The manuscript management system is completely online and includes a very quick and fair peer-review system, which is all easy to use. Visit http://www.dovepress.com/testimonials.php to read real quotes from published authors.

Submit your manuscript here: http://www.dovepress.com/therapeutics-and-clinical-risk-management-journal 